\title{
Strength Properties of Concrete using Stone Dust as a Replacement Material for Fine Aggregate
}

\author{
A. Arunya, R. Chitra, Thendral S
}

\begin{abstract}
Fine total is one of the significant material in the planning of cement. Concrete is most generally utilized in development materials Major segments of cement are totals which are typically accessible in regular structure. The interest for waterway sand in the development business has therefore expanded because of the broad utilization of cement. The huge scale exhaustion of common sand makes ecological issues, for example, soil disintegration, disappointment of waterway banks, bringing down of stream bed, saline water interruption into the land. To evade these sort of issues and to save common assets fine total utilized in concrete is supplanted by stone residue. Utilization of stone residue in concrete improve the nature of concrete as well as go about as reasonable elective material for common stream sand for who and what is to come. In the present examination a trial program was done to consider the quality and properties of regular solid utilizing stone residue concrete in M45 grade. In view of the test examinations led, it is presumed that the stone residue is best option for the fine total since fine total and stone residue has comparable physical and mechanical properties. It is discovered that $40 \%$ supplanting of fine total with stone residue invigorates conspicuous than customary cement.
\end{abstract}

Keywords - Stone dust, Conplast SP430, Compressive strength \&Split tensile strength

\section{INTRODUCTION}

The Ordinarily Concrete is a composite material made of bond, fine total, coarse total and water. At present development industry is becoming exponentially because of a few other factor other than expanding formative exercises. This outcomes in colossal interest of development materials. Significant segments of cement are totals which are generally accessible in characteristic structure. Fine Aggregate utilized in concrete is normally waterway sand accessible locally or at close by area[1]. The interest for waterway sand in the development business has thusly expanded because of the broad utilization of cement bringing about the decrease of sand sources and increment in price.Going for elective and advantageous material which can be utilized as fractional or full substitution of ordinary material can assume a crucial job in preservation of common assets. Because of quick development of development movement, the accessible

Revised Manuscript Received on October 22, 2019.

A. Arunya, Department of Civil Engineering, Bharath Institute of Higher Education and Research, Chennai , India. Email: arunyaaaa@gmail.com

R. Chitra, Department of Civil Engineering, Bharath Institute of Higher Education and Research, Chennai, India. Email: chitraroopauma@gmail.com

Thendral S, Department of Civil Engineering, Bharath Institute of Higher Education and Research, Chennai , India. Email: thendral.cs@gmail.com wellsprings of common sand are getting depleted. Consequently preservation of regular assets is extraordinary test for structural designers since development exercises can't be reduced as it is personal capable. The main route is to look through choices material which can completely or halfway supplanted normally accessible material in development. Stone dust is such an elective material which can be successfully being utilized in development as incomplete substitution of normal sand[2]. Thus an examination is completed to recognize reasonable substitute that is eco-accommodating, cheap and better for quality execution

\section{MATERIALS}

\section{A) Fine Aggregate}

Locally accessible stream sand going totally through $4.75 \mathrm{~mm}$ opening size strainer and adjusting to zone-II according to IS:383-1970 particular is used in this investigation. The fundamental test was completed and the test outcomes are classified in Table 1.

Table - 1 Properties of sand

\begin{tabular}{|c|c|}
\hline Properties & Values \\
\hline $\mathrm{D}_{60}, \mathrm{~mm}$ & 1.80 \\
\hline $\mathrm{D}_{30, \mathrm{~mm}}$ & 1.30 \\
\hline $\mathrm{D}_{10, \mathrm{~mm}}$ & 0.66 \\
\hline $\mathrm{Cc}$ & 1.42 \\
\hline $\mathrm{Cu}$ & 2.72 \\
\hline Classification & S.P \\
\hline
\end{tabular}

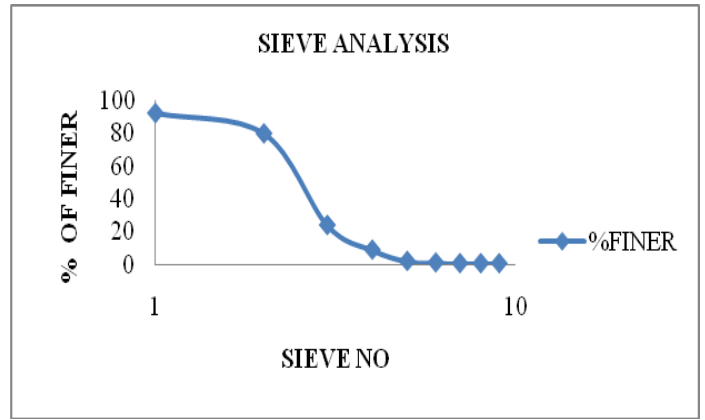

Figure - 1 Grain size distribution of soil

\section{B. Coarse Aggregate}

Locally accessible waterway sand going totally through $4.75 \mathrm{~mm}$ opening size sifter and adjusting to zone-II according to 
IS:383-1970 determination is used in this examination[3]-[5]. The primer test was done and the test outcomes are arranged in Table 2.

Table - 2 Properties of coarse aggregate

\begin{tabular}{|c|c|}
\hline Properties & Values \\
\hline Specific Gravity & 2.7 \\
\hline Impact Value \% & 27.3 \\
\hline Crushing Value \% & 17.5 \\
\hline Water absorption \% & 0.10 \\
\hline Abrasion value \% & 14.2 \\
\hline Bulk Density & 1219 \\
Loose condition & 1425 \\
\hline
\end{tabular}

\section{Cement}

In this examination Ordinary Portland Cement (OPC) 43 evaluation of single cluster was utilized adjusting to IS 8112:1989 details. Properties of OPC are recorded beneath in Table. 3

Table - 3 Properties of Cement

\begin{tabular}{|c|c|}
\hline Properties & Values \\
\hline Finess $\%$ & 8 \\
\hline Nomal consistency $\%$ & 33 \\
\hline Initial setting time & $30 \mathrm{~min}$ \\
\hline Final setting time & $187 \mathrm{~min}$ \\
\hline Specific gravity & 3.15 \\
\hline
\end{tabular}

\section{Stone dust}

Stone dust got from the devastating plant at kasbapuram local zone of kanchipuram District in Tamilnadu[6]-[10]. It was dark in shading, dry in condition, used as a thoroughlyretained on 150 micron sifter for whole investigation. The properties of the material are classified in Table. 4

Table - 4 Properties of stone dust

\begin{tabular}{|c|c|}
\hline Properties & Values \\
\hline Bulk Density $\left(\mathrm{Kg} / \mathrm{cm}^{3}\right)$ & 18.1 \\
\hline Specific gravity & 2.6 \\
\hline Bulking of sand \% & 4.9 \\
\hline Finess modulus & 2.4 \\
\hline Water Absorption \% & 6.2 \\
\hline
\end{tabular}

\section{E. Conplast SP430}

In this investigation conplast SP430 is utilized to give magnificent speeding up of solidarity gain at early ages and significant increments in quality at all ages by altogether diminishing water request in a solid blend and furthermore to makes conceivable significant decreases in water: bond proportion which permit the generation of high quality cement without inordinate concrete substance. According to May be: 9103-1999 detail. It is in fluid structure which is dark colored in shading which has a decent consolidating property with water. The properties of Sp430 are classified in Table.6

Table.6 Properties of Conplast (SP430)

\begin{tabular}{|c|c|}
\hline Properties & Values \\
\hline Appearance & Brown in liquid \\
\hline Specific gravity & 1.2 \\
\hline Chloride content & Nil \\
\hline
\end{tabular}

\section{METHODOLOGY}

\section{A. Fresh concrete Workability}

To decide consistency of solid, Slump test was led. Usefulness as droop test for consistency of each bunch of solid blend complies with IS:1199-1959 details was done. Droop estimated was recorded regarding millimeter of subsidence of the example during test.The aftereffects of droop esteem are organized in Table.7[26]-[29]

Table.7 Slump Test Values

\begin{tabular}{|c|c|c|}
\hline Mix & Type & $\begin{array}{c}\text { Slump } \\
\text { value, } \mathrm{mm}\end{array}$ \\
\hline Mix-1 & Conventional Concrete & 90 \\
\hline Mix-2 & $40 \%$ of Stone dust with SP & 39 \\
\hline Mix-3 & $40 \%$ of stone dust without SP & 70 \\
\hline Mix-4 & $100 \%$ of Stone dust with SP & 37 \\
\hline Mix-5 & $100 \%$ of Stone dust without SP & 48 \\
\hline
\end{tabular}

Figure - 2 Graphical representation of Slump Value

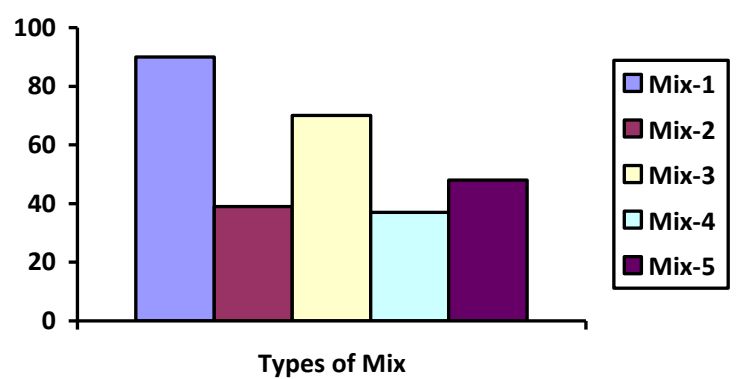

\section{B. Compressive Test}

The shape specimens $(150 * 150 \mathrm{~mm})$ were tried for compressive quality toward the finish of 7 days and 28 days.

The examples were tried after surface of the example dried[11]-[14]. The heap was 
applied on the smooth sides without stun and expanded constantly until the disappointment of the example. The most extreme burden withstand by the examples is noted, mean compressive quality is resolved and introduced in Table. 8 and Table.9

Table.8 Compressive strength test results @ 7 days

\begin{tabular}{|c|c|c|c|c|}
\hline \multirow[t]{2}{*}{ Mix } & \multirow[t]{2}{*}{ Type } & \multicolumn{3}{|c|}{$\begin{array}{c}\text { Compressive } \\
\text { strength.N/mm } \mathrm{mm}^{2}\end{array}$} \\
\hline & & Trail-1 & Trail-2 & Trail-3 \\
\hline Mix-1 & $\begin{array}{l}\text { Conventional } \\
\text { Concrete }\end{array}$ & 47.2 & 48.8 & 46.3 \\
\hline Mix-2 & $\begin{array}{c}40 \% \text { of Stone dust } \\
\text { with SP }\end{array}$ & 49.9 & 49.4 & 49.0 \\
\hline Mix-3 & $\begin{array}{c}40 \% \text { of stone dust } \\
\text { without SP }\end{array}$ & 46.3 & 46.9 & 46.6 \\
\hline Mix-4 & $\begin{array}{c}100 \% \text { of Stone dust } \\
\text { with SP }\end{array}$ & 44.3 & 45.0 & 44.2 \\
\hline Mix-5 & $\begin{array}{c}100 \% \text { of Stone dust } \\
\text { without SP }\end{array}$ & 43.8 & 43.7 & 44.1 \\
\hline
\end{tabular}

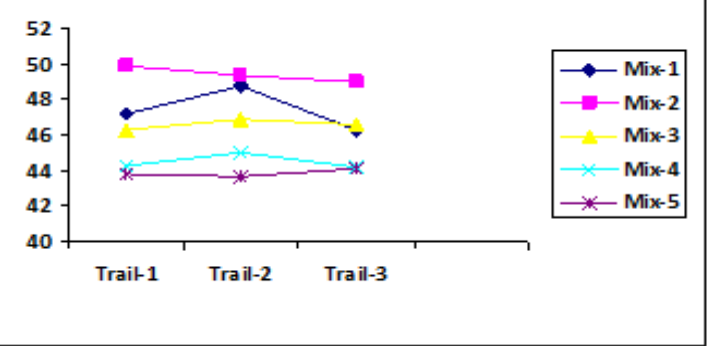

Figure - 2 Graphical representation of Compressive Strength @ 7 days

Table.9 Compressive strength test results @ 28 days

\begin{tabular}{|c|c|c|c|c|}
\hline \multirow[t]{2}{*}{ Mix } & \multirow[t]{2}{*}{ Type } & \multicolumn{3}{|c|}{$\begin{array}{l}\text { Compressive strength, } \\
\qquad \mathrm{N} / \mathrm{mm}^{2}\end{array}$} \\
\hline & & Trail-1 & Trail-2 & Trail-3 \\
\hline Mix-1 & $\begin{array}{l}\text { Conventional } \\
\text { Concrete }\end{array}$ & 47.23 & 48.82 & 46.33 \\
\hline Mix-2 & $\begin{array}{c}40 \% \text { of Stone dust } \\
\text { with SP }\end{array}$ & 49.93 & 49.47 & 49.09 \\
\hline Mix-3 & $\begin{array}{c}40 \% \text { of stone dust } \\
\text { without SP }\end{array}$ & 46.34 & 46.95 & 46.66 \\
\hline Mix -4 & $\begin{array}{c}100 \% \text { of Stone dust } \\
\text { with SP }\end{array}$ & 44.34 & 45.00 & 44.29 \\
\hline Mix-5 & $\begin{array}{c}100 \% \text { of Stone dust } \\
\text { without SP }\end{array}$ & 43.84 & 43.71 & 44.11 \\
\hline
\end{tabular}

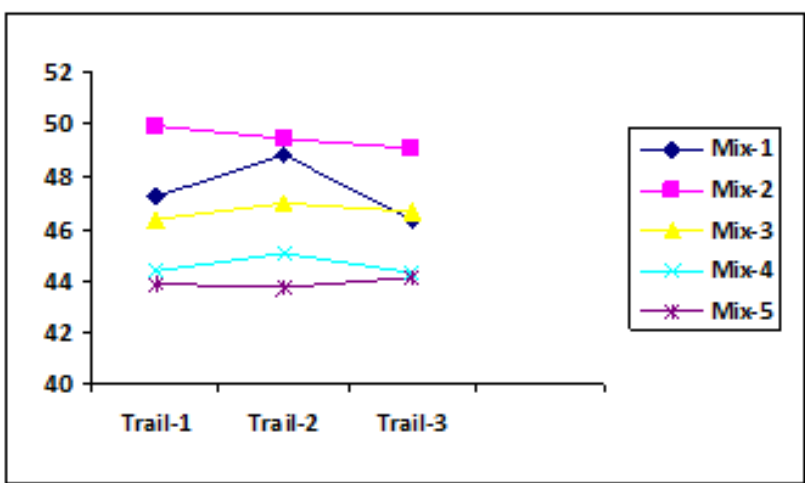

Figure - 3 Graphical representation of Compressive Strength @ 28 days

\section{Split Tensile strength Test}

A chamber of example $100 \mathrm{~mm}$ dia and $200 \mathrm{~mm}$ length were tried for split rigidity toward the finish of 7 days and 28 days[30]-[34]. Parting rigidity test on solid chamber is a strategy to decide the elasticity of cement. The solid is extremely frail in strain because of its fragile nature and isn't relied upon to oppose the immediate pressure[15]-17]. The solid creates breaks when exposed to ductile powers. In this way, it is important to decide the rigidity of cement to decide the heap at which the solid individuals may split. The aftereffects of the split elasticity are arranged in Table.10 and Table. 11

Table.10 Split Tensile strength test results @ 7 days

\begin{tabular}{|c|c|c|c|c|}
\hline \multirow[t]{2}{*}{ Mix } & \multirow[t]{2}{*}{ Type } & \multicolumn{3}{|c|}{$\begin{array}{c}\text { Split Tensile Strength, } \\
\qquad \mathrm{N} / \mathrm{mm}^{2}\end{array}$} \\
\hline & & Trail-1 & Trail-2 & Trail-3 \\
\hline Mix-1 & $\begin{array}{c}\text { Conventional } \\
\text { Concrete }\end{array}$ & 4.30 & 4.34 & 4.13 \\
\hline Mix-2 & $\begin{array}{l}40 \% \text { of Stone dust } \\
\text { with SP }\end{array}$ & 4.78 & 4.77 & 4.73 \\
\hline Mix-3 & $\begin{array}{c}40 \% \text { of stone dust } \\
\text { without SP }\end{array}$ & 4.54 & 4.60 & 4.45 \\
\hline Mix-4 & $\begin{array}{c}100 \% \text { of Stone dust } \\
\text { with SP }\end{array}$ & 4.11 & 4.09 & 4.17 \\
\hline Mix-5 & $\begin{array}{c}100 \% \text { of Stone dust } \\
\text { without SP }\end{array}$ & 3.92 & 3.96 & 4.13 \\
\hline
\end{tabular}




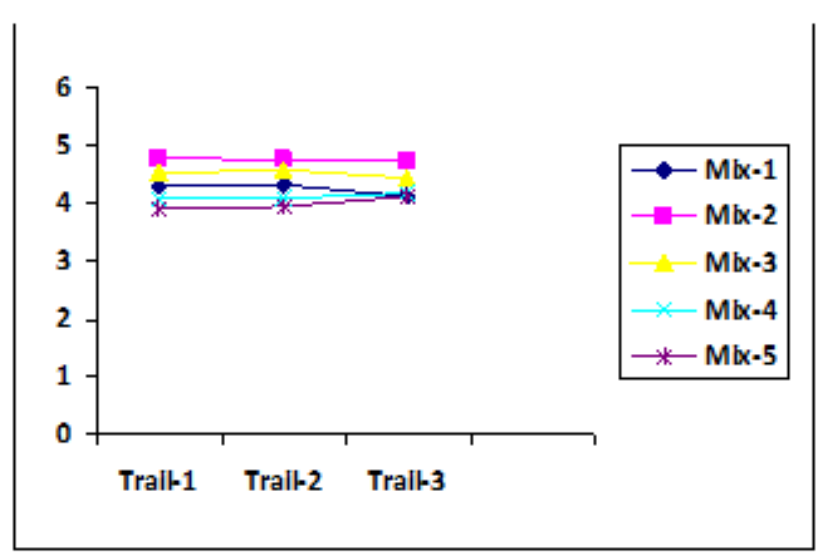

Fig.4 Graphical representation of Split Tensile Strength @ 7days

Table - 11 Split Tensile strength test results @ 28 days

\begin{tabular}{|c|c|c|c|c|}
\hline \multirow[t]{2}{*}{ Mix } & \multirow[t]{2}{*}{ Type } & \multicolumn{3}{|c|}{$\begin{array}{l}\text { Split Tensile Strength, } \\
\mathrm{N} / \mathrm{mm}^{2}\end{array}$} \\
\hline & & Trail-1 & Trail-2 & Trail-3 \\
\hline Mix-1 & $\begin{array}{c}\text { Conventional } \\
\text { Concrete }\end{array}$ & 6.44 & 6.42 & 6.45 \\
\hline Mix-2 & $\begin{array}{c}40 \% \text { of Stone dust } \\
\text { with SP }\end{array}$ & 6.98 & 7.04 & 6.95 \\
\hline Mix-3 & $\begin{array}{c}40 \% \text { of stone dust } \\
\text { without SP }\end{array}$ & 6.31 & 6.29 & 6.32 \\
\hline Mix-4 & $\begin{array}{c}100 \% \text { of Stone dust } \\
\text { with SP }\end{array}$ & 5.81 & 5.84 & 5.87 \\
\hline Mix-5 & $\begin{array}{c}100 \% \text { of Stone dust } \\
\text { without SP }\end{array}$ & 5.68 & 5.71 & 5.71 \\
\hline
\end{tabular}

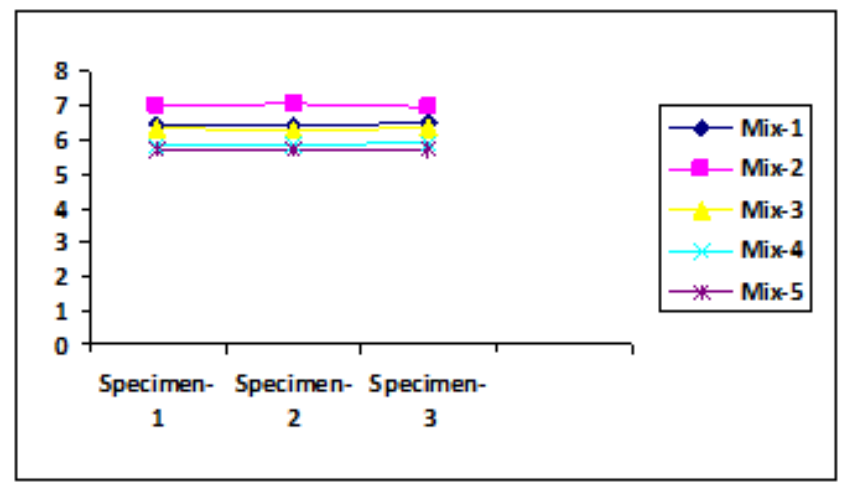

Figure - 5 Graphical representation of Split Tensile Strength@ 28 days

\section{RESULTS AND DISCUSSION}

Compressive quality and Split Tensile quality of the solid 3D square and Cylinder examples was determined by separating the most extreme burden applied to the example during the test by the cross-sectional area[18]-[22].The normal of three estimations of compressive quality was taken as the delegate compressive quality and Split Tensile quality. In test block and chamber example was put in the CTM machine in such way that the heap applied to the contrary sides of the examples as cast that isn't to the top and base according to IS;516;1959 particulars.

An absolute number of 60 solid 3D shape and chamber examples as a gathering of 12 3D squares ( $33 \mathrm{D}$ squares and 3 chambers for 7 days and 3 blocks and 3 chambers for 28 days test )were thrown with 5 diverse blends in with the expansion of superplasticizer.40\% and $100 \%$ supplanting of common stream sand with stone dust with and without superplasticizer and drenched completely in consumable water for restoring and tried for 7 days and 28 days compressive and split pliable strength[23]-[25].The normal results for compressive and split rigidity for 7 and 28 days are organized in Table 12 and Table 13.

Table - 11 Compressive strength test results @ 7 \& 28 days

\begin{tabular}{|c|c|c|c|c|}
\hline Grade & Mix & Type of mix & $\begin{array}{l}7 \text { days Axg } \\
\text { Compressiv } \\
\text { e Strength, } \\
\mathrm{N} / \mathrm{mm}^{2}\end{array}$ & $\begin{array}{c}28 \text { days Axg } \\
\text { Compressive } \\
\text { Strength, } \\
\mathrm{N} / \mathrm{mm}^{2}\end{array}$ \\
\hline \multirow{5}{*}{$\mathrm{M}_{45}$} & Mix-1 & $\begin{array}{l}\text { Conventiona } \\
\text { l Concrete }\end{array}$ & 40.27 & 47.45 \\
\hline & Mix-2 & $\begin{array}{c}40 \% \text { of } \\
\text { Stone dust } \\
\text { with SP }\end{array}$ & 42.10 & 49.49 \\
\hline & Mix-3 & $\begin{array}{c}40 \% \text { of } \\
\text { stone dust } \\
\text { without SP }\end{array}$ & 41.74 & 46.65 \\
\hline & Mix-4 & $\begin{array}{c}100 \% \text { of } \\
\text { Stone dust } \\
\text { with SP }\end{array}$ & 38.24 & 44.54 \\
\hline & Mix-5 & $\begin{array}{l}100 \% \text { of } \\
\text { Stone dust } \\
\text { without SP }\end{array}$ & 36.35 & 43.88 \\
\hline
\end{tabular}

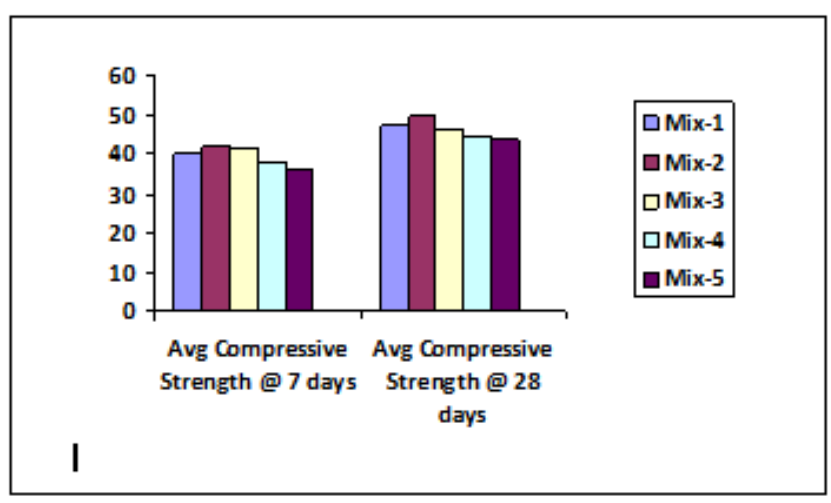

Figure - 6 Graphical representation of Compressive Strength@ $7 \& 28$ days

Published By:

Blue Eyes Intelligence Engineering

\& Sciences Publication 
Table - 12 Split Tensile strength test results @7 \& 28 days

\begin{tabular}{|c|c|c|c|c|}
\hline Grade & Mix & Type of mix & $\begin{array}{l}7 \text { days Axg } \\
\text { SplitTensile } \\
\text { Strength, } \\
\mathrm{N} / \mathrm{mm}^{2}\end{array}$ & $\begin{array}{c}28 \text { days Axg } \\
\text { Split Tensile } \\
\text { Strength, } \\
\mathrm{N} / \mathrm{mm}^{2}\end{array}$ \\
\hline \multirow{5}{*}{$\mathrm{M}_{45}$} & Mix-1 & $\begin{array}{l}\text { Conventiona } \\
\text { l Concrete }\end{array}$ & 4.3 & 6.4 \\
\hline & Mix-2 & $\begin{array}{c}40 \% \text { of } \\
\text { Stone dust } \\
\text { with SP }\end{array}$ & 4.7 & 6.9 \\
\hline & Mix-3 & $\begin{array}{c}40 \% \text { of } \\
\text { stone dust } \\
\text { without SP }\end{array}$ & 4.5 & 6.3 \\
\hline & Mix-4 & $\begin{array}{c}100 \% \text { of } \\
\text { Stone dust } \\
\text { with SP }\end{array}$ & 4.1 & 5.8 \\
\hline & Mix-5 & $\begin{array}{l}100 \% \text { of } \\
\text { Stone dust } \\
\text { without SP }\end{array}$ & 3.9 & 5.6 \\
\hline
\end{tabular}

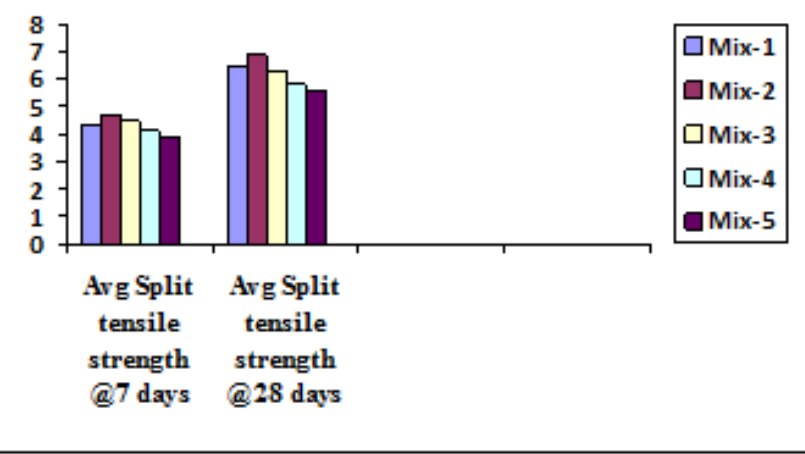

\section{Figure - 7 Graphical representation of Split tensile strength @ 7 \& 28 days}

\section{V.CONCLUSION}

Based on the results and discussions, the following points are concluded,

i. Slump of cement made utilizing stone residue diminishes with increment in substitution level

ii. There is a critical increment in both compressive and split malleable test at $40 \%$ substitution of stone residue.

iii. Stone residue can be utilized as one of the substitute for Fine total if there should be an occurrence of non-accessibility of normal waterway sand at a sensible expense.

\section{REFERENCES}

1. Iyappan L., Dayakar P., Identification of landslide prone zone for coonoortalukusing spatial technology, International Journal of Applied Engineering Research,V-9,I-22,PP-5724-5732,Y-2014.

2. Kumar J., Sathish Kumar K., Dayakar P.,Effect of microsilica on high strength concrete, International Journal of Applied Engineering Research,V-9,I-22,PP-5427-5432,Y-2014.

3. Dayakar P., Vijay Ruthrapathi G., Prakesh J., Management of bio-medical waste, International Journal of Applied Engineering Research,V-9,I-22,PP-5518-5526,Y-2014.

4. Swaminathan N., Dayakar P., Resource optimization in construction project, International Journal of Applied Engineering Research,V-9,I-22,PP-5546-5551,Y-2014.

5. Venkat Raman K., Dayakar P., Raju K.V.B.,An experimental study on effect of cone diameters in penetration test on sandy soil, International Journal of Civil Engineering and Technology,V-8,I-8,PP-1581-1588,Y-2017.

6. Saritha B., Chockalingam M.P.,Photodradation of malachite green DYE using TIO2/activated carbon composite,International Journal of Civil Engineering and Technology,V-8,I-8,PP-156-163,Y-2017

7. Shendge R.B., Chockalingam M.P., Saritha B., Ambica A.,Swat modelling for sediment yield: A case study of Ujjani reservoir in Maharashtra, India,International Journal of Civil Engineering and Technology,V-9,I-1,PP-245-252,Y-2018

8. Chockalingam M.P., Balamurgan V.,Modernisation of an existing urban road-sector in Chennai, a case study report,International Journal of Civil Engineering and Technology,V-8,I-8,PP-1457-1467,Y-2017

9. Saritha B., Chockalingam M.P.,Adsorption study on removal of basic dye by modified coconut shell adsorbent, International Journal of Civil Engineering and Technology,V-8,I-8,PP-1370-1374,Y-2017

10. Saritha B., Chockalingam M.P.,Adsorptive removal of heavy metal chromium from aqueous medium using modified natural adsorbent,International Journal of Civil Engineering and Technology,V-8,I-8,PP-1382-1387,Y-2017

11. Chockalingam M.P., Palanivelraja S.,Retrospective analysis of a theoretical model used for forecasting future air quality near the north Chennai thermal power plant,International Journal of Civil Engineering and Technology,V-8,I-8,PP-1457-1467,Y-2017

12. Saritha B., Chockalingam M.P.,Photodegradation of methylene blue dye in aqueous medium by $\mathrm{Fe}-\mathrm{AC} / \mathrm{TiO} 2$ Composite,Nature Environment and Pollution Technology,V-17,I-4,PP-1259-1265,Y-2018

13. Shendge R.B., Chockalingam M.P., Kaviya B., Ambica A.,Estimates of potential evapotranspiration rates by three methods in upper Bhima Basin, In Maharashtra, India,International Journal of Civil Engineering and Technology,V-9,I-2,PP-475-480,Y-2018

14. Shendge R.B., Chockalingam M.P.,The soil and water assessment tool for Ujjani Reservoir,International Journal of Mechanical Engineering and Technology,V-9,I-2,PP-354-359,Y-2018

15. Shendge R.B., Chockalingam M.P.,A review on soil and water assessment tool,International Journal of Mechanical Engineering and Technology,V-9,I-2,PP-347-353,Y-2018

16. Sachithanandam P., Meikandaan T.P., Srividya T.,Steel framed multi storey residential building analysis and design,International Journal of Applied Engineering Research,V-9,I-22,PP-5527-5529,Y-2014

17. Meikandaan T.P., Ramachandra Murthy A.,Study of damaged RC beams repaired by bonding of CFRP laminates,International Journal of Civil Engineering and Technology,V-8,I-2,PP-470-486,Y-2017

18. Meikandaan T.P., Ramachandra Murthy A.,Retrofittng of reinforced concrete beams using GFRP overlays, International Journal of Civil Engineering and Technology,V-8,I-2,PP-423-439,Y-2017

19. Meikandaan T.P., Ramachandra Murthy A.,Flexural behaviour of RC beam wrapped with GFRP sheets,International Journal of Civil Engineering and Technology,V-8,I-2,PP-452-469,Y-2017

20. Meikandaan T.P., Murthy A.R.,Experimental study on strengthening of rc beams using glass Fiber,International Journal of Civil Engineering and Technology,V-9,I-11,PP-959-965,Y-2018

21. Meikandaan T.P., Hemapriya M.,Use of glass FRP sheets as external flexural reinforcement in RCC Beam,International Journal of Civil Engineering and Technology,V-8,I-8,PP-1485-1501,Y-2017

22. Saraswathy R., Saritha B.,Planning of integrated satellite township at Thirumazhisai,International Journal of Applied Engineering 
Research,V-9,I-22,PP-5558-5560,Y-2014

23. Saritha B., Ilayaraja K., Eqyaabal Z.,Geo textiles and geo synthetics for soil reinforcement,International Journal of Applied Engineering Research,V-9,I-22,PP-5533-5536,Y-2014

24. Ambica A., Saritha B., Changring G., Singh N B., Rajen M., Salman Md.,Analysis of groundwater quality in and around Tambaram taluk, Kancheepuram district,International Journal of Civil Engineering and Technology,V-8,I-8,PP-1362-1369,Y-2017

25. Arunya A., Sarayu K., Ramachandra Murthy A., Iyer N.R.,Enhancement of durability properties of bioconcrete incorporated with nano silica,International Journal of Civil Engineering and Technology,V-8,I-8,PP-1388-1394,Y-2017

26. Ilayaraja K., Krishnamurthy R.R., Jayaprakash M., Velmurugan P.M., Muthuraj S.,Characterization of the 26 December 2004 tsunami deposits in Andaman Islands (Bay of Bengal, India),Environmental Earth Sciences,V-66,I-8,PP-2459-2476,Y-2012

27. Ilayaraja K.,Morphometric parameters of micro watershed in Paravanar sub-basin, Cuddalore District,International Journal of Civil Engineering and Technology,V-8,I-8,PP-1444-1449,Y-2017

28. Ilayaraja K., Singh R.K., Rana N., Chauhan R., Sutradhar N.,Site suitability assessment for residential areas in south Chennai region using remote sensing and GIS techniques,International Journal of Civil Engineering and Technology,V-8,I-8,PP-1468-1475,Y-2017

29. Ilayaraja K., Reza W., Kumar V., Paul S., Chowdhary R.,Estimation of land surface temperature of Chennai metropolitan area using Landsat images,International Journal of Civil Engineering and Technology,V-8,I-8,PP-1450-1456,Y-2017

30. Chitra R.,Experimental study on beam using steel fiber and latex,International Journal of Civil Engineering and Technology,V-8,I-8,PP-1395-1403,Y-2017

31. Chitra R.,Analysis of traffic and management at Kovilambakkam intersection,International Journal of Civil Engineering and Technology,V-8,I-8,PP-1433-1443,Y-2017

32. Aswathy M.,Experimental study on light weight foamed concrete,International Journal of Civil Engineering and Technology,V-8,I-8,PP-1404-1412,Y-2017

33. Aswathy M.,Wastewater treatment using constructed wetland with water lettuce (Eichornia Crasipies),International Journal of Civil Engineering and Technology,V-8,I-8,PP-1413-1421,Y-2017

34. Kiruthiga K., Anandh K.S., Gunasekaran K, Assessment of influencing factors on improving effectiveness and productivity of construction engineers, 2015, International Journal of Applied Engineering Research, V - 10,I -17,p -13849-13854.

\section{AUTHORS PROFILE}

A. Arunya Assistant Professor, Department of Civil Engineering, Bharath Institute of Higher Education and Research, Chennai , India.

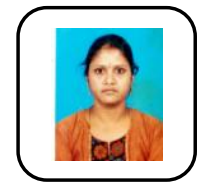

R. Chitra, Assistant Professor, Department of Civil Engineering, Bharath Institute of Higher Education and Research, Chennai , India.

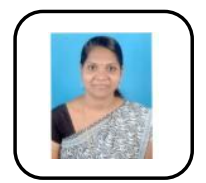

Thendral S, Assistant Professor, Department of Civil Engineering, Bharath Institute of Higher Education and Research, Chennai , India. 